\title{
Cities in Fiction: Perambulations with John Berger
}

\author{
Christian De Cock \\ Essex Business School \\ University of Essex \\ Wivenhoe Park \\ Colchester CO4 3SQ \\ $U K$ \\ christian.decock9@gmail.com
}




\section{Cities in Fiction: Perambulations with John Berger}

This paper explores selected novels by John Berger in which cities play a central role. These cities are places, partially real and partially imagined, where memory, hope, and despair intersect. My reading of the novels enables me to trace important themes in recent discourses on the nature of contemporary capitalism, including notions of resistance and universality. I also show how Berger's work points to a writing that can break free from the curious capacity of capitalism to absorb and feed of its critiques.

Keywords: Berger, Capitalism, Fiction, Resistance, Universality, Critique 


\section{Cities in Fiction: Perambulations with John Berger}

History is not something that one understands, it is something one endures - if one is lucky. (White 2007, 110)

People in free societies don't have to fear the pathology of the state. We create our own frenzy, our own mass convulsions... The frenzy is barely noticeable most of the time. It's simply how we live. (DeLillo 2003, 85)

\section{Preamble: A stroll through the City}

Friday May $13^{\text {th }} 2005$, and I am strolling through London's Square Mile with John Berger. Not just me and him, of course. There are about forty of us talking about, wandering through, and sensing the financial heart of the London metropolis. Later we leave the imposing buildings behind and end up in the pub where there are to be more stories and a discussion on the nature of contemporary capitalism and possibilities of resistance. The genesis of this event - or as the organizers, Platform, put it: "the lifeboat" - could be found in John Berger's fiction. Platform (2005, 85) particularly referred to Berger's (1979) Pig Earth, as an "absolute inspiration that another world was possible".

--- Insert figure 1 about here: 'A stroll through the City' ---

In this article I revisit the themes explored on that memorable walk through my reading of a selection of Berger's books. First I consider the Into their Labours trilogy, and in particular its final part Lilac and Flag: an Old Wives' Tale of the City (1990) which is set in the harsh urban reality of Troy, an imaginary Uber-Metropolis. This allows me to introduce Berger's particular views on hope and resistance under the condition of late capitalism. The novel King: A Street Story (1999), described as a "furious homage to the homeless", unfolds in a similarly unforgiving urban setting. A close reading of passages from the book enables me to elaborate on Berger's treatment of those excluded from, or in the margins of, society and to relate this to the concept of universality. In one of 
Berger's most recent books the reflections on the city take a more personal turn. Here is Where We Meet (2005) offers an amalgam of novel, essay and autobiography in which a character called John Berger meets his beloved dead in various European cities (London, Lisbon, Madrid, Krakow, Geneva). Here the connection between John Berger's life and writing takes centre stage. Finally, with Don DeLillo's (1993) Metropolis I contextualize Berger's writings on resistance and explore how they can point to a writing that can break free from capitalism's spellbinding power; a power to recycle and feed of its critiques. This is particularly pertinent in the context of critical management studies where, to quote Thrift $(2006,301)$, "theory, in its attempt to be fast-moving and productive, is increasingly trying to mimic the very forces that may endanger it".

\section{Cities, fiction, and organization studies}

Berger's fictional perambulations through cities would be familiar to most of his readers. Much of Berger's project, spanning seven decades now and comprising of novels, plays, film and documentary scripts, poetry, art criticism, drawings, and a few less easily categorisable activities, has been concerned with revealing 'other spaces'. Soja $(1989,22)$ singled him out as an intensely (critical) spatial thinker who dwells on the intersection of time and space in virtually all his writing ${ }^{1}$, thus offering us "a balancing of history and geography, lineage and landscape, period and region”. Soja was particularly taken by a fragment of a sentence in The Look of Things (Berger 1972, 40) which he quotes again and again throughout his books: "it is space not time that hides consequences from us" (e.g. 1989, 22, 23, 61; 2000, 165, 166). Cities, especially the ones featuring in Lilac and Flag and King, are emblematic of the process of urbanization which Lefebvre (2003) already in the 1960s considered as central to the survival of capitalism. This process gradually obliterates the distinctions between town and country through the production of integrated spaces across national territories, and it is always the poor and those marginalized from political power who suffer first and foremost from this, something Harvey $(2008,34)$ referred to as "accumulation by dispossession”. Berger's preferred way of documenting this process is through the medium of narrative fiction. In this respect his work has important connections with that of Marshall Berman. Not only in the narrative tour-de-force of examining the relation of capitalism and urbanizaton through 
fiction (in Berman's case Paris, St. Petersburg, and New York), but also in offering "a perspective that resists all final resolutions, aesthetic or political, that wrestles boldly with its own inner contradictions, and that can illuminate" (Berman 1983, 134).

Recent scholarship in organization studies also has become increasingly attentive to the reading of narrative fiction in its attempts to illuminate subject matter of particular relevance to the field. It would take us too far to survey all of this work (for comprehensive overviews, see for example, De Cock and Land 2006; Land and Sliwa 2009; Lilley and McKinlay 2009). I will limit myself here to a brief overview of two excellent recent examples that bring together the themes of fiction, resistance, and space, and thus serve as a useful platform for my own explorations of Berger's fiction. Beyes (2009, 426) reads Pynchon's Against the Day (2006) "as a highly critical dramatization of society's socio-political struggles that is aware of its co-implication in the world it is painting". Here resistance or a "hunting for spaces of escape", is a precarious enterprise which is always about to be colonized by what it seeks to oppose or transgress. Whilst Pynchon in his search for heterotopic spaces tries to give voice to what is left out from the master narrative of capitalist modes of organizing, Beyes (2009) points out how this endeavour is always in danger of being cancelled out by its dependence on the very regime it seeks to confront. Pynchon is very aware of this, of course. Beyes quotes a narrator commenting on the fate of an uprising: "[ . . . the Madero revolution has moved on, specifically south to the Capital, where it lost no time in lapsing into some urban professional's fantasy of liberal democracy" (Pynchon 2006, 982). Rhodes $(2009,397)$ reads Bukowski's Factotum (1975) as "an experiment with, and testimony to, the experience of resistance in the context of capitalist work relations". As Chinaski, Factotum's main character, drifts from city to city and from meaningless job to meaningless job, Bukowski sketches the life of an underclass, "people [who] experience a weariness beyond fatigue" $(1975,46)$. In many ways Bukowski's works deals with a reality of work largely ignored in the academic study of organizations, one that is experienced 'from below'. Chinaski finds that whilst he cannot escape the consequences of capitalist work relations, neither can he remain inside them. Resistance is futile, but not to resist is equally impossible. Yet, it is the possible reality of freedom and the 
resistance to power that keeps him going somehow. Rhodes $(2009,395)$ puts it thus: "For Bukowski resistance is not something that can be said, it has to be lived, and to live it is so hard that it borders on impossibility".

\section{Into their Labours: Resistance and "endurance within the impossible"}

In his Into Their Labours trilogy Berger explores the themes of resistance and hope, including their conditions of (im)possibility, as experienced by those who see socioeconomic life 'from below'. The trilogy comprises Pig Earth (1979), Once in Europa (1987) and Lilac and Flag (1990). O'Grady (2005, 22) described the books as "a record of the leakage of village into metropolis, of meaning into incoherence", and went on to praise it as "one of the great works in English of the past half century".

In the first two books of the Into Their Labours trilogy Berger documents life in a peasant village in the French Alps as it begins to unravel under increasing contact with the big cities. He makes us witness the clash between a mentality of survival and intergenerational continuity on the one hand, and that of the market mentality of the capitalist outside world on the other (Taylor 2006). In these novels the peasants seem to have preserved a sense of history and an experience of time and place, as opposed to that propagated by late capitalism which seems to revel in obliterating the past and creating spatial deliria (Berger 1998). Berger's peasantry tales thus offer us a tangible reminder of a different way of living. Whilst it would take us too far to explore the literature on peasantry - incidentally one that is noticeable by its absence in organization studies useful connections can be made with Brecht's fictional exploration of peasant history to contrast capitalist and pre-capitalist modes of production. Of course, in doing so we must guard against the antiquarianism such a move may entail. As Berger $(1978,358)$ suggested, "[N]obody can reasonably argue for the preservation of the traditional peasant way of life, but to dismiss peasant experience as having no relevance to modern life is to deny the value of too much history and too many lives”. For both Brecht and Berger peasant life is the vehicle through which one is able to represent the experience of the exploited and the oppressed. The residual culture that peasantry represents is always necessarily resistant to the newer forms of capitalist development, and its view of history 
holds open a redemptive moment - the hope that history possesses something that will redeem it; a hope which is by no means unconditional however. As Jameson elaborated, "Brecht's inclusion of a dimension of peasant history was not some ideological blockage or limit on his part; rather, that dimension was necessary in order to recapture and represent the note of Hope it could alone afford" (Jameson 1998, 140).

In Lilac and Flag Berger documents the lives of the children of the peasants he wrote about in the first two volumes of Into Their Labours as they are scattered to the big cities. It allows him to pursue themes central to his body of work: the increasing lack of continuity in modern life, the fading of the distinction between the urban and the rural, the effect of forced migrations to the city, and the resultant fate of those living on the margins of the city. He collects images from the industrial and postindustrial landscapes of Troy; a megapolis situated in the near future which stands for all huge cities. Troy is "where all are driven to, ringed with fast roads, girded with banks and building sites, helmeted with the sulphurous haze of fume" (Waters 1992, 87). Whilst Troy is described as a $21^{\text {st }}$ century city (e.g., p.86), we encounter here a wide variety of 19th-century phenomena: forced urban restructuring, vast zones of poverty, glaring inequalities, and the pitilessness of the strong. As such, the world of Troy is remarkably similar to the one described by Pynchon (2006) in Against the Day. It is a place where capitalism has run the film of history backwards. Berger sums up Troy thus in Lilac and Flag:

It is possible you have been to Troy without recognising the city. The road from the airport is like many others in the world. It has a superhighway and is often blocked. You leave the airport buildings which are like space vessels never finished, you pass the packed car parks, the international hotels, a mile or two of barbed wire, broken fields, the last stray cattle, billboards that advertise cars and Coca-Cola, storage tanks, a cement plant, the first shanty town, several giant depots for big stores, ring-road flyovers, working-class flats, a part of an ancient city wall, the old boroughs with trees, crammed shopping streets, new golden office-blocks, a number of ancient domes and spires, and finally you arrive at the acropolis of wealth. (p.170) 
In this book Berger offers us not so much a critique as a 'struggle towards truthfulness'. Words are carefully chosen, enticing the reader to come as close as possible to the experiences described. For Berger 'truth' is a question of the precision of the words: "If a writer is not driven by a desire for the most demanding verbal precision, the true ambiguity of events escapes him" (Berger 1991, 217). He makes us aware of the urgent need to discover what has always-already been there but has been ignored, and "to have the courage to see what is waiting to be seen", as he put it in an interview in Berlin (Berger 2007b). In this respect his work makes interesting connections with Badiou's project (cf. "To force to see something, as if it was practically impossible, something that is anyhow clearly visible...” Badiou 2006, 144). In Lilac and Flag Berger's protagonists, whom Badiou (2006) would call the 'anonymous excluded', scrape a living by working on a building site (of Mond Bank!), by taking blood pressure readings of passers-by, by selling coffee out of a thermos, by dancing in a strip bar, or by trafficking stolen passports. Troy no longer offers the sense of a future slowly unfolding.

And what we live now is what? asked his son. Don't ask me. I don't know. It's not history. It's a kind of waiting. (p.41)

There is only the rush to win some monetary gain here and there in Troy. There is no longer any glimpse of an elsewhere or an otherwise, "there are no pauses, no paths, no pattern, no past and no future" (Berger 1998, 1). Lilac and Flag offers a vision of society as seen from below, by those who have experienced only repeated failure. Yet, amidst all the ruined lives John Berger detects an 'undefeated despair', to coin one of his beautifully evocative phrases (Berger 2006b, 602) ${ }^{3}$. It has affinities with Badiou's (2008, 41) notion of 'courage', which the latter conceives of as a virtue manifesting itself through "endurance within the impossible", and it emphasizes "the necessity and the urgency of keeping the impossible alive, keeping faith with it, making it continue to be somehow possible in its very impossibility" (Jameson 1999, 59).

If we keep the idea of justice alive under our yellow helmets, Murat said, if we all keep it alive together, one day the world will belong to us...

My father dreamt of the village he left, and you, you dream of the future. Meanwhile we're here, you and I are here, mixing concrete for the Mond Bank... 
In history things often happen when nothing seems to be happening.

Like some nights.

Yes, history has nights and days, said Murat.

And now it's night?

Now it's night, it's been night for a long while. (pp. 59-60)

Somewhere amidst all the devastation Berger thus glimpses moments of grace, something profoundly affirmative: "Not a promise, for (almost) all promises are broken; rather

something like a bracket, a parenthesis in the otherwise remorseless flow of history... It's an acceptance which peers behind the adversity and discovers there something nameless" (Berger 2006a, 33). Berger is close here to Benjamin's (2002) notion of 'weak messianic power'. His 'undefeated despair', evoking feelings of impossibility and dashed hopes, is a kind of hope that is no longer connected to an expected success. It is something very different from optimism because in the world Berger depicts there is not really much room for hope. Jameson $(1999,62)$ describes it thus: "the messianic does not mean immediate hope... perhaps not even hope against hope; it is a unique variety of the species hope that scarcely bears any of the latter's normal characteristics and that flourishes only in a time of absolute hopelessness,... when radical change seems unthinkable, its very idea dispelled by visible wealth and power, along with palpable powerlessness". The allegory drawn from King (Berger 1999) quoted below gives the reader a glimpse of how Berger represents this 'undefeated despair' and 'endurance within the impossible'.

\section{King - A Street Story: The excluded as connection to the universal}

"In this book you will be led to a place you haven't been, from where few stories come. You will be led by King, a dog (or is he?) to a wasteland beside the motorway..." (publisher's synopsis).

A boy is throwing it [a ball] against a blind wall in a square where there's a cheap fish restaurant. It's shut now. The boy has been doing this for what seems to him a long time. 
There are no surprises left; he has learnt by heart the wall and the ball, and both of them are as listless as he is.

To make a little change - it is much more difficult to change anything than you talkers believe - he decides to catch the ball as it comes back, at the very last moment, before it bounces on the paving stones between the stains and the scraps of paper and the dog shit and the fish bones. He watches the ball coming, he waits, he savours the moment of doing nothing when he's at one with the overwhelming force which makes it so difficult to change anything, and he stoops forward to catch the ball a hand's breadth from the ground. The next time the ball comes a little harder and after the sweetly drawn-out wait, all he has to do is to bend his knees and catch it between his heels.

The third time he misjudges and the ball hits the ground. He does nothing, he waits as before but far longer. He stares at the wall, the wall stares at the ball which rolled and was stopped by an empty beer can. The ball stares at the boy, the boy scratches his tummy and goes on waiting. Three cats are stretched out hungry and asleep by the fish restaurant.

Eventually the boy goes dutifully to pick up the ball and he returns to his old position before the wall. He will start again. What else? (pp.81-82)

Law $(2004,88)$ defined allegory as "the art of meaning something other and more than what is being said... it is the art of decoding that meaning, reading between the literal lines to understand what is actually being depicted". The use of allegory points to the difficulty, or even impossibility, of the representation of the deeper and relational realities of capitalist societies. As Jameson $(2007,196)$ elaborated, “[A]llegory happens when you know you cannot represent something but you also cannot not do it”. Representation becomes problematic in capitalist societies because they are uniquely attuned to singular events, one-off transactions and interventions (Sennett 2006); they are characterized by "the lack of any continuity existing between one action and the next which is close to be touching it" (Berger 1998, 3). A particular universal anthropological model is put forward: that of the homo œconomicus, or rather Homo Economicus 2.0 (HE 2.0) as Callon (2007) calls the $21^{\text {st }}$-century form of agency required to survive and prosper in a market society. This model in turn strengthens the power and effectiveness of markets as 
networks of innovation. Homo Economicus 2.0 is solely responsible for his successes and failures, and can never share the load of his 'mistakes'. The universality the model lays claim to is a false one though, as in a properly dialectical reading there can never be a pure incarnation of the universal. The universal is a conceptual construction that can never know any precise empirical embodiment or realization; it can only be through exceptions which are scattered throughout the situation that one arrives at the universal. These exceptions appear as a non-essential or contingent disturbance to the dominant order (as such they do not even exist from an official point of view). A system that does not wish to be recognised as a system will want to do away with its universal elements so that "when you come upon particulars in that system that would allow you to deduce the universal, or to make connections to the universal again, those connections, I think, always have to be made allegorically...(Jameson 2007, 168)”.

John Berger has developed a wonderful skill of rendering visible this world that from the official viewpoint does not exist; of constructing the visibility of a non-existence in other words. His protagonists move around the city, but are never part of it; indeed they are hardly ever noticed unless they commit 'a crime'. In King this 'crime' consists simply of the fact that they exist. Precisely because of their position in society, the 'anonymous excluded' Berger's novels focus on become the stand-in for that society in its universality. They are the 'part of no part' of the social body (Rancière 2004). As Žižek (2004b, 70) puts it: "This identification of the non-part with the Whole, of the part of society with no properly defined place within it (or resisting the allocated subordinate place within it) with the Universal, is the elementary gesture of politicization, discernible in all great democratic events..." Berger evokes this position of 'the part of no part' beautifully in two passages from King.

The hatred which the strong feel for the weak as soon as the weak get too close is particularly human; it doesn't happen with animals. With humans there is a distance which must be respected, and when it isn't, it is the strong, not the weak, who feel affronted, and from the affront comes hatred. (p.24) 
A mistake, King, is hated more than an enemy. Mistakes don't surrender as enemies do. There's no such thing as a defeated mistake. Mistakes either exist or they don't, and if they do, they have to be covered over. We are their mistake, King. Never forget that. (p.211)

Berger thus explores the ways in which the meaningful fabric of the sensible is disturbed: his protagonists do not fit within the framework defined by a network of meanings; they cannot find a place in the system of visible coordinates where they appear (cf. Rancière, 2004). In the final Berger book considered in this article the focus shifts from the anonymous excluded to the author himself. Cities now become a vehicle to reflect on Berger's own life, and in particular the connection between his lived experience and his writing and reading.

\section{Here is Where We Meet}

“Let my dead help me now” (Berger 1990, 4)

In Here Is Where We Meet, the narrator (John) visits cities he loves and meets there friends both living and dead. The narrative drifts gently across maps and memories from city to city, and from beloved dead to beloved dead - in a series of loosely connected stories and reflections. Space seems to become a tool for transcending history's remorseless flow as the encounters with his dead seem linked to particular cities. Berger sees these various cityscapes through a veil of time as layered entities in which he perambulates in a hallucinatory and at the same time vivid manner. They are described most lovingly, but also as somewhat out of joint.

Do you see? she suddenly said. Everything is broken, slightly broken, like the rejects from the factory they sell cheap, at half price. Not really damaged, only rejects. Everything - the hills, the Sea of Straw, the child's swing down there, the car, the castle, everything is a reject, and has been so since the beginning. (p.50)

The book is characterised by the absence of a conventional narrative or plot. Rather, what Berger offers is a mellow, seemingly autobiographical journey which seems to unfold in that different durée Badiou alluded to (cf. note 4), thus connecting our world to another order of time and space. For example, in the chapter on the Chavet caves he explores the 
comforting notion that "something that has gone, or is awaited, is hidden elsewhere in another place". Yet, as the stories move through time and space, the writing never loses its acute sense of place. Cities acquire a physical and sensual quality as they are represented as full of things and people to be smelt, tasted, and touched. Talking to the dead is simply an alternative way of seeing and thinking about the world and its (im)possibilities.

In the first story John (the narrator) meets his mother, who died fifteen years earlier, in Lisbon. Together they explore the city as she keeps appearing and disappearing.

Yet you are not really here, are you?

How stupid can you get! We - us - we are all here. Just like you and the living are here. You and us, we are here to repair a little of what was broken. This is why we occurred.

Occurred?

Came to be.

You talk as if nobody can choose anything!

Choose whatever you like. What you can't do is to hope for everything. (p.51)

In Krakow John has a beer with Ken, a mentor from childhood. While waiting for sculptor Juan Muñoz (another one of his 'dead') in a Madrid hotel bar lounge, he comes across an old tutor "who died in his fifties soon after the second world war". In another story John and his daughter Katya pay a visit to Borges's grave in Geneva. To ask what the stories mean or what the larger purpose of the book amounts to is to put the wrong question. Reflecting on his formative reading through books supplied by Ken, John says: Neither of us, for different reasons, believed in literary explanations. I never once asked him about what I failed to understand. He never referred to what, given my age and experience, I might find difficult to grasp in these books... There was a tacit understanding between us that we learn - or try to learn - how to live partly from books. The learning begins with looking at our first illustrated alphabet, and goes on until we die. (p.88)

Berger, in the winter of his life (the book was published when he was 79), wants to find out (and hence to teach us through his self-questioning) how it is we learn to live ${ }^{5}$. All the 
chapters (and much of his other recent work) are all the time probing and assessing his own life. The power of Berger's prose and poetry lies precisely in the fact that his life and his work have gradually become so very much intertwined. Collini's $(2008,16)$ recent description of Raymond Williams's life project is apposite to John Berger's life:

What is compelling arises out of a peculiarly intense and hard-to-disentangle blending of life and work, personality and writing, background and purpose. That deep centredness and confidence in who he was; that massive, calm certainty about central human values; that constant bringing back of intellectual and literary issues to a half-remembered, half-idealised experience of genuine community, grounded in the everyday solidarities of working-class life; that unremitting effort to find an idiom and a form adequate to the representation of this experience...

The beginnings of this blending of life and work were already apparent in Berger's art criticism from the 1950s. Berger never insisted that art itself be used to convey any particular ideological message. Yet, for him art is political in that its purpose is to create a new collective based on a new mode of perception; there exists a clear affinity between a certain kind of thought and a certain kind of art. Again he is close here to Benjamin who suggested that, under the cover of distraction, revolutionary political and social meaning can be transmitted by art (Ferris 2008).

I can't tell you what art does and how it does it, but I know that art has often judged the judges, pleaded revenge to the innocent and shown to the future what the past has suffered, so that it has never been forgotten. I know too that the powerful fear art, whatever its form, when it does this, and that amongst the people such art sometimes runs like a rumour and a legend because it makes sense of what life's brutalities cannot, a sense that unites us, for it is inseparable from a justice at last. Art, when it functions like this, becomes a meeting-place of the invisible, the irreducible, the enduring, guts and honour. (Berger 1991, 9)

In the introduction to a collection of selected essays Dyer pointed out how John Berger arranged his life in such a way as to seek out the experiences appropriate to his particular 
gift: "Particularly in the later works his writing is, if you like, a measure of how far he has gone beyond the mere ability to write" (Dyer 2001, xi). Berger does not see words as transparent: "One does not look through writing on to reality - as through a clean or dirty window-pane" (Berger 1991, 214). The credibility of words involves a strange dialectic. It is the writer's openness to ambiguity and uncertainty of any experience, even the experience of certainty, which gives clarity, and thus a kind of certitude to the writing. Form and content have to bleed together. Authenticity in writing comes from the fidelity to the ambiguity of experience. As Latour $(2005,126)$ suggested, social scientific writing has a lot to learn from the kind of narrative fiction that is as "obsessed by textual quality" as it is "enslaved by reality". Berger's writing, of course, is itself an expression of 'undefeated despair',

I risk to write nonsense these days.

Just write down what you find.

I'll never know what I've found.

No, you'll never know. All you have to know is whether you're lying or whether you're trying to tell the truth, you can't afford to make a mistake about that distinction any longer ... (p.237)

\section{Final Reflections: Lessons in Resistance}

“Today's elite realize the dream of yesterday's marginal philosophers and outcast artists (from Spinoza to Nietzsche and Deleuze). In short, and stated even more pointedly, the thought of Foucault, Deleuze, and Guattari, the ultimate philosophers of resistance, of marginal positions crushed by the hegemonic power network, is effectively the ideology of the newly emerging ruling class" (Žižek 2004a, 303-304).

In his typically flamboyant style Žižek touches here upon "the famed power of capitalism for recycling everything aimed at its destruction" (Latour 2004, 231). The once scandalous desire for creativity, transgression and difference articulated by situationist and deconstructionist critics merely seems to echo the vocabulary of management textbooks these days (Kemple 2007). Even powerful critiques of our social order and the 
conceptualizations of alternatives to it, have proved very quickly to be the unfortunate replication of its most fundamental tendencies (Buchanan 2006). Boltanski and Chiapello $(2005,27)$ have explored at great length this dialectic of capitalism and its critiques; how capitalism's very survival is dependent on its extraordinary capacity to absorb anticapitalist forces: "it needs its enemies, people whom it outrages and who are opposed to it”. Boltanski and Chiapello $(2005,41)$ suggest that critique is disarmed in a process of “ideological neutralization (critique no longer knows what to say), not physical neutralization (it knows what to say, but cannot say it or does not succeed in making itself heard)". All we are left with is a capacity for indignation. Even protest movements seem to have become integral to the dynamics of capitalism.

Don DeLillo's (2003) novel Cosmopolis, set in New York City, evokes this predicament brutally and concisely. The novel covers a single day in the life of multi-billionaire hedge fund manager Eric Packer who owns a forty-eight-room Manhattan apartment and a decommissioned nuclear bomber. Near Times Square he gets caught up in a carnivalesque anti-capitalist protest. His car is attacked and vandalised and his security people "go ape". Yet Packer is hugely enjoying the spectacle:

This is the free market itself. These people are a fantasy generated by the market. They don't exist outside the market. There is nowhere they can go to be on the outside. There is no outside... The market culture is total. It breeds these men and women. They are necessary to the system they despise. They give it energy and definition... This is why they exist, to invigorate and perpetuate the system. (p.90)

Cars are burning, advertising slogans are being daubed in graffiti, police are advancing behind riot shields, smoke hovers everywhere, pandemonium reigns in New York City. Then something happens:

It was exhilarating, his head in the fumes, to see the struggle and ruin around him... The protest was a form of systemic hygiene, purging and lubricating. It attested again, for the ten thousandth time, to the market culture's innovative brilliance, its ability to shape itself to its own flexible ends, absorbing everything around it. Now look. A man in flames. Behind Eric all the screens were pulsing with it... 
The market was not total. It could not claim this man or assimilate his act. Not such starkness and horror. This was a thing outside its reach. (p.97-100)

This is the killer blow DeLillo delivers in Cosmopolis. The only thing that escapes capitalism's reach is self-destructive violence. Žižek $(2008,64)$ could have been referring to this novel when writing: "The sad fact that opposition to the system cannot articulate itself in the guise of a realistic alternative, or at least a meaning ful utopian project, but only take the shape of a meaningless outburst, is a grave illustration of our predicament. What does our celebrated freedom of choice serve, when the only choice is between playing by the rules and (self-) destructive violence?"

The fact that our raw capacity for indignation can no longer be translated into effective critical theories need not be as disconcerting as Boltanski and Chiapello suggest. Badiou (2006, 35) provides an alternative, and perhaps at a first glance passive, image of "the attic where, in difficult times, one accumulates resources, lines up tools and sharpens knives... an ample reserve of means to other forms of thought". Berger's writing, which can be read as a resonating participant in the realities it describes, offers us such an 'attic', aimed at preserving and sustaining alternative modes of thought through dark times. This is captured in a beautiful reflection on what shape a resistance might take that cannot be incorporated into the current order and that does not degenerate into selfdestructive violence.

In the dark age in which we are living under the new world order, the sharing of pain is one of the essential preconditions for a refinding of dignity and hope. Much pain is unshareable. But the will to share pain is shareable. And from that inevitably inadequate sharing comes a resistance. (Berger 2002,164)

For Berger the peasant experience of survival seems better adapted to the extensions and elaborations of corporate capitalism in all its brutality than a continually reformed disappointing, impatient hope of revolution. Indeed, in one of his most recent books he explicitly links the notion of resistance to that of survival (Berger 2007a). To start formulating an answer to the question of what now/here is to be done requires paying attention to the reach of local experiences and to moments of life directly lived; to the 
specificity of being alive at a particular place and time. And it is in the representation of this kind of life that Berger's fiction excels. Berger creates situations in which the real, the possible, and the impossible co-exist, thus bringing out a spectral dimension of given realities. Having the real and the possible and yet, at the same time, maintaining the difference between them is a process that can only be staged in fiction: "It is the author's selection from and textual representation of the real world that can create a matrix for the possible to emerge" (Iser 1997, 5).

Žižek (2004b, 77), in an afterword to Rancière's (2004) The Politics of Aesthetics, puts across pithily the potential of Berger's kind of writing: "These poetic displacements and condensations are not just secondary illustrations of an underlying ideological struggle, but the very terrain of this struggle... disturbing such orders of the visible and proposing different lateral links of the visible, unexpected short-circuits, etc., is the elementary form of resistance". He refers here to Rancière's vision of an art that transmits meanings in the form of a rupture with the logic of meaningful situations. It is not enough that it leads us to an awareness of the state of the world. It has to produce simultaneously a double effect: "the readability of a political signification and a sensible or perceptual shock caused, conversely, by the uncanny, by that which resists signification" (Rancière 2004, 63). Berger may provide such Rancièrian perceptual shifts and disturbances of the visible, but these certainly offer no easy answers. Indeed, how could there be such in a writing that does not allow one to look on to reality "as through a clean or dirty window pane" (Berger 1991, 214), and that continuously struggles with its own contradictions and impossibilities. For example, Berger is utterly undeterred from trying to achieve an almost impossible balance between representations of the oppression of the excluded and representations of their heroism. By insisting on the oppression, he is in danger of emphasizing the weakness of the excluded and their failure to overcome their situation. In insisting on their heroism and valour, he could be accused of projecting a set of political possibilities which do not really exist (Jameson 2007). But even if Berger's writings on life under late capitalism may sometimes appear theoretically contradictory, they always retain their capacity to move us. Ultimately Berger's long life/work project is best summarized by the title of a 1998 essay: "Against the Great Defeat of the World". He 
borrowed this title from a poem by Juan Gelman with which he concluded that essay. I believe it is also a fitting way to end my own effort.

death itself has come with its documentation/

we're going to take up again

the struggle/ again we're going to begin

again we're going to begin all of us

against the great defeat of the world/

little compañeros who never end / or

who burn like fire in the memory

again / and again / and again 


\section{References}

Badiou, A. 2006. Polemics (S. Corcoran, Trans.). London: Verso.

Badiou, A. 2008. The communist hypothesis. New Left Review, 49: 29-42.

Beckett, S. 1997. Molloy, Malone dies, the unnamable. New York: Everyman's Library.

Benjamin, W. 2002 (1927-1940). The arcades project (H. Eiland, \& K. McLaughlin, Trans.). Cambridge (MA): Harvard University Press.

Berger, J. 1972. The look of things: Selected essays and articles. London: Pelican.

Berger, J. 1978. Towards understanding peasant experience. Race \& Class, 19(4): 345359.

Berger, J. 1979. Pig Earth. London: Bloomsbury.

Berger, J. 1984. And our faces, my heart, brief as photos. London: Bloomsbury.

Berger, J. 1987. Once in Europa. London: Bloomsbury.

Berger, J. 1990. Lilac and Flag: An old wives' tale of the city. London: Bloomsbury.

Berger, J. 1991. Keeping a rendezvous. New York: Vintage.

Berger, J. 1998. Against the great defeat of the world. Race \& Class, 40(2/3): 1-4.

Berger, J. 1999. King: A street story. London: Bloomsbury.

Berger, J. 2002. The shape of a pocket. London: Bloomsbury.

Berger, J. 2005. Here is where we meet. London: Bloomsbury.

Berger, J. 2006a. Dispatches. Race \& Class, 48(1): 23-41.

Berger, J. 2006b. Undefeated Despair. Critical Inquiry, 32(Summer): 602-609.

Berger, J. 2007a. Hold everything dear: Dispatches on survival and resistance. London: Verso.

Berger, J. 2007b. In den Falten der Zeit, Die Zeit, Vol. 01.03 (10).

Berman, M. 1983. All that is solid melts into air: The experience of modernity. London: Verso.

Beyes, T. 2009. An aesthetics of displacement: Thomas Pynchon's symptomatology of organization. Journal of Organizational Change Management, 22(4): 421-436.

Boltanski, L., \& Chiapello, È. 2005. The new spirit of capitalism (G. Elliott, Trans.). London: Verso.

Buchanan, I. 2006. Fredric Jameson: Live theory. London: Continuum. 
Bukowski, C. 1975. Factotum. Santa Rosa, CA: Black Sparrow Books.

Callon, M. 2007. An essay on the growing contribution of economic markets to the proliferation of the social. Theory, Culture \& Society, 24(7-8): 139-163.

Collini, S. 2008. Upwards and onwards. London Review of Books, 30(15): 13-16.

De Cock, C., \& Land, C. 2006. Organization/Literature: Exploring the seam.

Organization Studies, 27(4): 517-535.

DeLillo, D. 2003. Cosmopolis. New York: Picador.

Derrida, J. 1994. Specters of Marx. London: Routledge.

Dyer, G. 2001. Editor's introduction to 'John Berger: Selected essays'. In G. Dyer (Ed.), John Berger: Selected essays. London: Vintage.

Ferris, D. 2008. The Cambridge introduction to Walter Benjamin. Cambridge:

Cambridge University Press.

Harvey, D. 2008. The right to the city. New Left Review, 53(5): 23-40.

Iser, W. 1997. The significance of fictionalizing. Anthropoetics: The Electronic Journal of Generative Anthropology, 3(2): 1-7.

Jameson, F. 1998. Brecht and method. London: Verso.

Jameson, F. 1999. Marx's purloined letter. In M. Spinker (Ed.), Ghostly demarcations: A symposium on Jacques Derrida's specters of Marx: 26-67. London: Verso.

Jameson, F. 2007. Jameson on Jameson: Conversations on cultural marxism. Durham (NC): Duke University.

Kemple, T. 2007. Spirits of capitalism. Theory, Culture \& Society, 24(3): 147-159.

Land, C., \& Sliwa, M. 2009. The novel and organization: introduction from the Editors. Journal of Organizational Change Management, 22(4): 349-356.

Latour, B. 2004. Why has critique run out of steam? From matters of fact to matters of concern. Critical Inquiry, 30(2): 225-248.

Latour, B. 2005. Reassembling the social: An introduction to actor-network theory. Oxford: OUP.

Law, J. 2004. After method: Mess in social science research. London: Routledge.

Lefebvre, H. 2003. The urban revolution (R. Bononno, Trans.). Minneapolis: University of Minnesota Press. 
Lilley, S., \& McKinlay, A. 2009. Matters of fact/matters of fiction: Imagining and implementing institutional change. Culture and Organization, 15(2): 129-133.

O’ Grady, T. 2005. Reading John Berger. In G. Evans (Ed.), John Berger: A season in London 2005: 22. London: Artevents.

Platform. 2005. Refusing to accept the absurdity of the world picture offered us. In G. Evans (Ed.), John Berger: A season in London 2005: 85. London: Artevents.

Pynchon, T. 2006. Against the day. London: Jonathan Cape.

Rancière, J. 2004. The politics of aesthetics: The distribution of the sensible (G. Rockhill, Trans.). London: Continuum.

Rhodes, C. 2009. "All I want to do is get that check and get drunk": Testifying to resistance in Charles Bukowski's Factotum. Journal of Organizational Change Management, 22(4): 386-401.

Sennett, R. 2006. The culture of the new capitalism. New Haven: Yale University Press.

Soja, E. W. 1989. Postmodern geographies: The reassertion of space in critical social theory. London: Verso.

Soja, E. W. 2000. Postmetropolis: Critical studies of cities and regions. Oxford: Blackwell.

Taylor, M. 2006. Rationality and the ideology of disconnection Cambridge: Cambridge University Press.

Thrift, N. 2006. Re-inventing invention: new tendencies in capitalist commodification. Economy and Society, 35(2): 279-306.

Waters, H. 1992. Review of 'Lilac and Flag'. Race \& Class, 34(1): 87-89.

White, H. 2007. Against historical realism: A reading of 'War and Peace'. New Left Review, 46 (4): 89-110

Žižek, S. 2004a. The ongoing 'soft revolution'. Critical Inquiry, 30(Winter): 292-323.

Žižek, S. 2004b. The lesson of Rancière, The politics of aesthetics: The distribution of the sensible: 69-79. London: Continuum.

Žižek, S. 2008. Violence: Six sideways reflections. London: Profile Books. 
Figure 1: A stroll through the City ${ }^{7}$

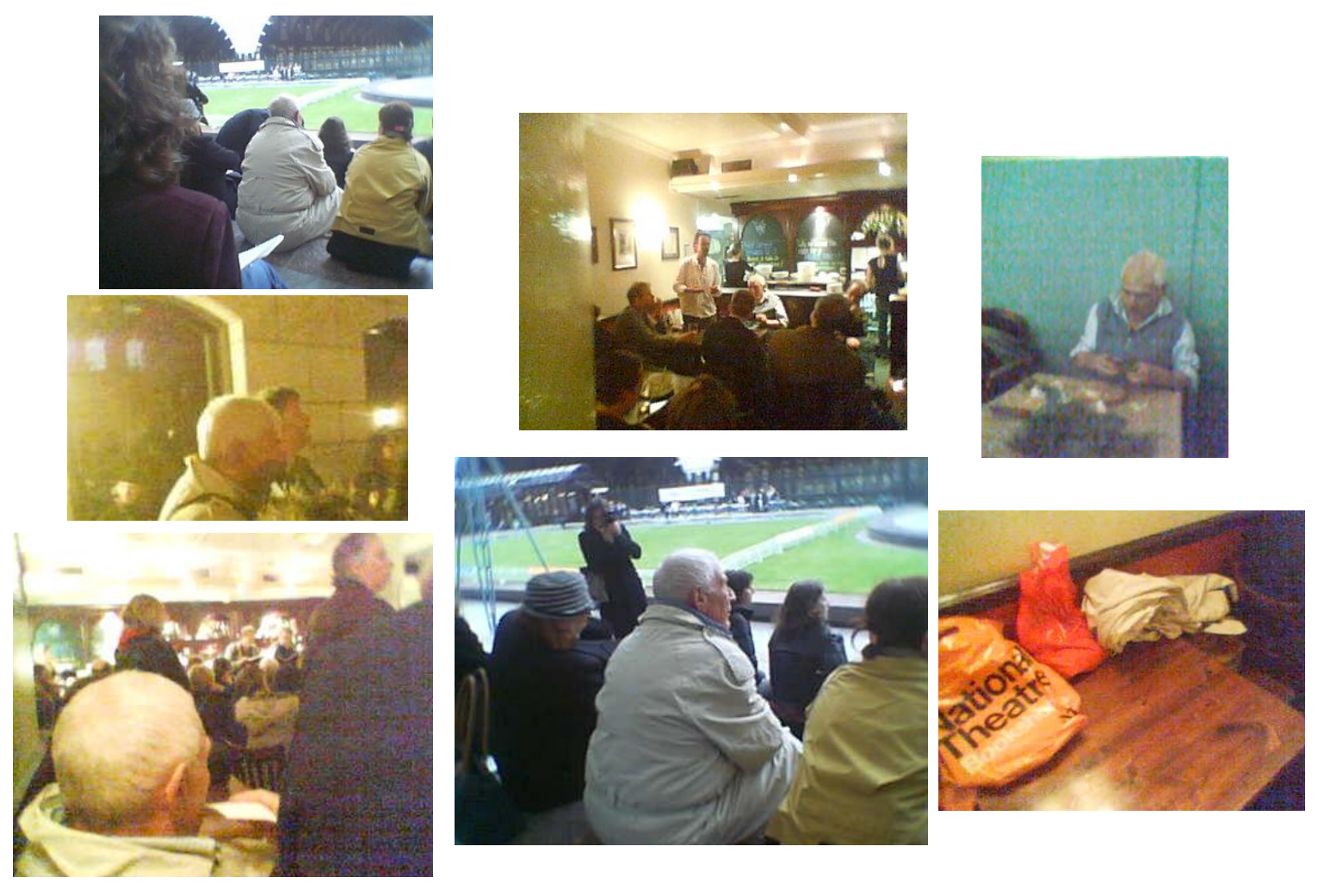




\section{NOTES}

${ }^{1}$ For example, And our Faces My Heart, Brief as Photos (Berger 1984) contains two parts: Part one ('Once') being about time, part two ('Here') being about space. Neither one is inherently privileged, both necessarily faceted together. Hold Everything Dear (Berger 2007a) mirrors this symmetry of time and space in its 'Ten Dispatches about Endurance' and 'Ten Dispatches about Place'. Here is Where we Meet 'describes as place a moment in which we temporarily dwell" according to Berger (2007b) in an interview for a German newspaper ("Es umschreibt als Ort einen Moment, in dem wir uns zeitweilig aufhalten”).

2 Badiou (2006, 34) described them as follows: "Today, outside of the grand and petty bourgeoisie of imperial cities who proclaim to be 'civilization', there is only the anonymous excluded. 'Excluded' is the name for those who have no name, just as 'market' is the name for a world that is not a world".

${ }^{3}$ He elaborates: "In the stance I keep referring to, there is something special, a quality that no postmodern or political vocabulary today can find a word for. The quality of a way of sharing that disarms the leading question: why was one born into this life?" (Berger 2006b, 609).

4 "The virtue of courage constructs itself through endurance within the impossible; time is its raw material. What takes courage is to operate in terms of a different durée to that imposed by the law of the world. The point we are seeking must be one that can connect to another order of time" (Badiou 2008, 41).

${ }^{5}$ This has echoes of Derrida's opening phrase of Specters of Marx (1994), "I would like to learn to live finally". It addresses the fear of modern people that they have not really lived, not yet lived or fulfilled their lives, in a world organized to deprive them of that satisfaction.

${ }^{6}$ We can trace parallels here with Wittgenstein's philosophical attitude which was not "I have got it right" but "Now I know how to go on". And then there are, of course, the famous last sentences in Beckett's (1997) 1953 novel The Unnamable (with thanks to the editors for pointing this out to me): 
I don't know, I'll never know: in the silence you don't know.

You must go on.

I can't go on.

I'll go on.

${ }^{7}$ All photos taken by C. De Cock, 13 May 2005. 